\title{
Język polski w statucie synodu łęczyckiego z 1285 roku - tłumaczenie kanonów
}

\author{
Polish language in the statute of the synod of Łęczyca of 1285 : \\ the translation of the canons
}

\author{
Wojciech Stelmach \\ Wydział Filologii Polskiej i Klasycznej, Uniwersytet im. Adama Mickiewicza w Poznaniu, \\ ul. Fredry 10, 61-701 Poznań, Polska; \\ e-mail: hcamletshceicjow@gmail.com
}

\begin{abstract}
Abstrakt
Przedmiotem badań w artykule jest stosunek polskiego episkopatu do języka polskiego w XIII wieku. Problem został przedstawiony w oparciu o statut synodu łęczyckiego z 1285 roku. Treść większości kanonów została przedstawiona w skrócie - tym samym przybliżono tematy, jakimi zajął się episkopat podczas synodu. Natomiast istotne dla historii języka polskiego kanony 3, 4 i 6 zostały poddane głębszej analizie. Podjęto próbę odtworzenia prawdopodobnej sytuacji panującej w Kościele na ziemiach polskich w XIII wieku oraz przedstawienia stosunku episkopatu do języka polskiego i jego wykorzystania w nauczaniu i liturgii. Ponadto na podstawie wydań źródłowych dokumentów kościelnych dokonano przekładu filologicznego wskazanych kanonów na język polski.
\end{abstract}

Słowa kluczowe: język polski; język łaciński; przekład; synod łęczycki; statut; kanon.

\begin{abstract}
The aim of this article is to present the attitude of the Polish Episcopate towards the Polish language in the $13^{\text {th }}$ century. The issue has been presented swith reference to the statute of the synod of Łęczyca of 1285. The content of most of the canons is briefly outlined together with the topics discussed by the Episcopate during the synod. Canons 3, 4, 5 and 6 - the most essential to the history of the Polish language - have been subjected to a deeper analysis; this enables us to recreate the most likely situation that prevailed in the Church in the $13^{\text {th }}$ century in Poland. They also present the Episcopate's attitude towards the Polish language and use thereof in teaching and liturgy. Moreover, a philological Polish translation of the above mentioned canons is based on the source editions of ecclesiastical documents.
\end{abstract}

Keywords: Polish language; Latin language; translation; synod of Łęczyca; statute; canon.

Dla badacza historii języka staropolskiego szczególnie cenne pod kątem poznawczym są konstytucje soborów powszechnych oraz statuty synodów prowincjonalnych. Pozwalają one w znacznej mierze określić stosunek władz kościelnych do wykorzystania języków wernakularnych w nauczaniu Kościoła oraz w liturgii. Ponadto dają podstawę do przedstawienia wpływu autorytetu na kształtowanie poglądów duchowieństwa na temat powyższych zagadnień. 
W XIII-wiecznej Polsce takim autorytetem był arcybiskup Jakub Świnka, który przewodząc działaniom polskiego episkopatu, nakierowanym na promowanie polszczyzny jako języka liturgii oraz ochronę kleru przed zniemczeniem, wydatnie przyczynił się do umocnienia statusu rodzimego języka względem łaciny.

W literaturze przedmiotu brak do dziś filologicznego przekładu kanonów zatwierdzonych na synodzie łęczyckim w 1285 roku, w tym tych, które bezpośrednio odnoszą się do wykorzystania języka polskiego w liturgii oraz nauczaniu powszechnym w szkołach klasztornych i katedralnych. Materiał ten stanowi istotny punkt odniesienia dla historyków języka, którzy badają przekształcenia statusu polszczyzny (czy w ogóle języków etnicznych) w średniowieczu, a także relacje łączące Kościół i język. Celem niniejszego artykułu jest uzupełnienie tej luki, a także analiza językowa poszczególnych kanonów. To pozwoli na nowo interpretować niektóre kwestie.

Materiały źródłowe do badań nad spuścizną synodów prowincjonalnych w Polsce zostały opublikowane do tej pory kilkukrotnie. Są to wydawnictwa jeszcze XIX-wieczne, jak np.: Starodawne prawa polskiego pomniki, t. 1, (Helcel 1856) i Antiquissimae constitutiones synodales provinciae gneznensis. Maxima ex parte. Nunc primum e codicibus manu scriptis typis mandatae (Hube 1856), a także seria Concilia Poloniae: źródta i studia krytyczne (Sawicki 1948-1963) oraz wydawane w Kolonii w latach 1963-1998 Schlesisches Urkundenbuch (Appelt, Irgang 1963-1998), zawierające m.in. teksty statutów synodalnych. Jak wspomniano, żadna $\mathrm{z}$ ww. edycji nie zawiera tłumaczenia kanonów. Brak przekładu może nastręczać badaczom historii języka polskiego wielu problemów. Bariera językowa często skutecznie utrudnia rzeczowe badania. Podręczniki do historii języka również nie są pomocne, bowiem podane w nich tłumaczenia lub streszczenia są niedokładne lub niestaranne. Na podstawie tak dokonanych przekładów ich autorzy często wyciągają mylne wnioski ${ }^{1}$, jak choćby Stanisław Rospond w swojej monografii Kościót w dziejach języka polskiego (Rospond 1985), powielane potem w kolejnych kompendiach i syntezach zagadnienia (więcej na ten temat zob. Stelmach 2014).

W szerokim spektrum działań, jakie podjął Świnka, na pierwszy plan wysuwa się ustawodawstwo synodalne episkopatu Polski, któremu przewodniczył metropolita gnieźnieński ${ }^{2}$. Władysław Karasiewicz przypisuje synodowi z 1285 roku

${ }^{1}$ Przede wszystkim Rospond, na podstawie tekstu kanonu 26. synodu legackiego, wyciąga wniosek o istnieniu świadomości narodowej u ludu zamieszkującego tereny rozbitgo państwa Piastów. Opiera swój sąd o przekład słów „,dicant publice in vulgari”, co znaczy dosłownie: „odmawiano publicznie w mowie ludu". Rospond nie wziął pod uwagę, że mowa ludu na XIII-wiecznym Śląsku, bo to tam odbywał się synod wrocławski, mogła oznaczać odmiany dialektalne polszczyzny, ale też języków niemieckiego i czeskiego. Jego interpretacja słów kanonu 26. była następnie powielana w opracowaniach autorstwa innych badaczy, np. Doroty Rojszczak-Robińskiej, Doroty Masłej oraz Izabeli Skierskiej.

${ }^{2}$ Jak podaje I. Subera w książce pt. Synody prowincjonalne arcybiskupów gnieźnieńskich. Wybór tekstów ze zbioru Jana Wężyka z r. 1761 (Subera 1981), statut synodu łęczyckiego z 1285 roku jest 
największe znaczenie spośród wszystkich synodów, które odbyły się w okresie rozbicia dzielnicowego (1948: 248) .

Synod w Łęczycy rozpoczął swe obrady w styczniu 1285 roku, a decyzje podejmował w składzie: arcybiskup gnieźnieński Jakub Świnka, biskup krakowski Paweł z Przemankowa, biskup poznański Jan, biskup płocki Tomasz, biskup włocławski Wisław oraz biskup wrocławski Tomasz. Episkopat zajął się sprawami najbardziej pilnymi, których po 12-letniej nieobecności metropolity gnieźnieńskiego zebrało się bardzo wiele.

Pierwszymi przepisami ${ }^{4}$, które uchwalił synod, były te regulujące sprawy kanoniczne. Po pierwsze do norm obowiązujących biskupów podczas wyświęcania kapłanów dodano informację, że pominięcie woli i wiedzy biskupa przy dopuszczaniu kapłanów do pracy duszpasterskiej lub przy objęciu przez nich dóbr jest niedopuszczalne. Karasiewicz wskazuje, że prawdopodobnie jest to wynik działalności na Śląsku księcia Henryka IV oraz mnichów i kleru niemieckiego. Ponadto przywoływano nakazy przystąpienia do sakramentu pokuty przed dokonaniem święceń oraz otrzymania poświadczenia przed przyjęciem beneficjum (Karasiewicz 1948: 249). W dalszej kolejności uchwalono kanony zobowiązujące biskupów do zakładania nowych kościołów, co z kolei miało wpłynąć na dokonywanie starannych spisów datków i sporządzanie potwierdzających to dokumentów, pieczętowanych przez biskupa i donatora. Postanowiono, aby dziesięciny od nowych kościołów były dokładnie określone, a nadwyżki dóbr przekazywane biskupom ${ }^{5}$.

W kwestii modlitw postanowiono, by pacierze kapłańskie odmawiane były głośno i wyraźnie, przypomniano też o obowiązku odmawiania niektórych modlitw, np. Salve regina i Exaudi domine ecclesiam tuam. $\mathrm{Z}$ ożywieniem kultu świętego Wojciecha, które było dla synodu ważne ze względów zdaje się przede wszystkim wizerunkowych ${ }^{6}$, wiązał się nakaz posiadania przez każdy kościół katedralny i klasztorny egzemplarza rymowanego oficjum o świętym Wojciechu, które miało być śpiewane.

$\mathrm{Na}$ archidiakonów nałożono obowiązek kontrolowania czystości ołtarza, kościoła i szat kapłańskich oraz odpowiedniego umiejscowienia Najświętszego Sakramentu i olejów przeznaczonych do udzielania sakramentów świętych.

najlepiej opracowanym zbiorem ustaw wydanych przez Jakuba Świnkę. W edycji przyjęto podział Bernarda z Pawii, który został rozpowszechniony przez Dekretały Grzegorza IX. Wcześniej na wzorowanie się na powszechnie przyjętym schemacie wskazywali T. Silnicki i K. Gołąb (1956: 120).

${ }^{3}$ Autor zwraca uwagę nie tylko na znaczenie polityczne (państwowe i kościelne), ale również historyczne, ze względu na zachowanie dokumentów synodalnych.

${ }^{4}$ Przedstawiona kolejność nie jest powtórzeniem układu kanonów z dostępnych źródeł, lecz oddaje porządek, jaki przyjął W. Karasiewicz w cytowanej książce (kierował się wagą omawianych spraw z punktu widzenia Kościoła).

${ }^{5}$ Według kanonu 26. z tych przepisów wyłączone zostały wspólnoty katedralne.

${ }^{6}$ Św. Wojciech był pierwszym polskim świętym męczennikiem, a w dodatku patronem Polski, nic więc dziwnego, że zbudowanie kultu jego osoby miało wpłynąć budująco na wiernych nie tylko w sferze metafizycznej, ale też świadomości narodowej. 
Ważnym postanowieniem biskupów było potępienie pobierania opłat za udzielanie sakramentów. Rozwiązano sprawy stosunków majątkowych między proboszczami a wikariuszami (tym drugim przydzielono stałe uposażenie w wysokości 5 grzywien). Nakazano również, aby kapłani bezzwłocznie spieszyli do chorych z posługą - ten kanon wynikał z tego, że hierarchowie byli świadomi opieszałości kleru przy świadczeniu posługi sakramentalnej. Przepisem, który miał dodatkowo dyscyplinować duchownych do obecności w swoich parafiach, był zakaz opuszczania diecezji i podejmowania służby w innej diecezji lub w innym charakterze bez zgody przełożonego biskupa.

Posłuszeństwo egzekwowano poprzez zaostrzenie przepisów związanych z odprawianiem nabożeństw w obecności osób objętych ekskomuniką - sprzeniewierzenie się zakazowi dodatkowo karane było suspensą, czyli odsunięciem od pełnienia funkcji kościelnych (w tym wypadku również sprawowania władzy nad dobrami ziemskimi). Osoby wspierające wrogów Kościoła miały utracić posiadane beneficja oraz stracić możliwość objęcia takowych w przyszłości.

Wprowadzono zakaz odstępowania posiadłości kościelnych osobom świeckim, natomiast w momencie przekazania ich mimo zakazu, nakazywano odebranie ich przez właściciela w ciągu roku od dokonania cesji. Umożliwiono natomiast odstępowanie ich innym duchownym, a w wyjątkowych okolicznościach również świeckim służącym Kościołowi.

Aby przeciwdziałać bigamii, synod nakazał zapowiedzi przedślubne. Dla zapewnienia bezpieczeństwa w kraju zarządzono, aby na mocy samego faktu objąć ekskomuniką rozbójników i napastników (Karasiewicz 1948: 251). Kanony określały też przypadki, w jakich można było u Żydów zastawiać przedmioty i księgi święte, a także zobowiązywały zarówno Hebrajczyków jak i chrześcijan do zwrotu skradzionych rzeczy bez uzyskania odszkodowania.

Pozostałe przepisy synodu z Łęczycy - omawiane przez historyków - dotyczyły bezpośrednio sprawy zatargu biskupa Tomasza z Henrykiem IV na Śląsku (zob. m.in. Karasiewicz 1948, Silnicki i Gołąb 1956, a także Skierska 2003: 184185). Historycy w swoich pracach na temat postanowień synodu nie poruszali jednak kwestii językowych. Dla historyka języka mają one ogromne znaczenie ze względu na zaprezentowane $\mathrm{w}$ ten sposób prawdopodobne poglądy na sprawę niemiecką zarówno polskiego episkopatu w ogóle, jak również abpa Jakuba Świnki (o Śwince jako „budzicielu świadomości językowej” zob. Rospond 1985, Skierska 2003, Rojszczak-Robińska 2010).

Wydane dwukrotnie w roku 1856 przez Antoniego Zygmunta Helcla w tomie I Starodawnych prawa polskiego pomników (Helcel 1856: 382-387) i Romualda Hubego w tomie Antiquissimae constitutiones synodales provinciae Gneznensis maxima ex parte nunc primum e Codicibus manu scriptis typis mandatae (Hube 1856: 165-180), statuty synodu łęczyckiego z 1285 roku w obu edycjach różnią się między sobą znacznie. Jak podaje Władysław Abraham, wydanie Helcla, opierające się na zbiorze statutów arcybiskupa Jarosława, zawiera 34 postanowienia (w niektórych wydaniach 36 - różnica wynika z rozbicia pojedynczych dłuższych 
kanonów na krótsze ${ }^{7}$ ), natomiast edycja Hubego składa się z 43 kanonów, a jej podstawę stanowią rękopisy petersburski i ze zbioru Biblioteki Baworowskich (1917: 55). Wątpliwości co do przynależności dodatkowych kanonów do zbioru praw Jakuba Świnki Abraham rozwiewa, wskazując, że w obu ww. rękopisach postanowienia 35-43 są oddzielone od poprzedzających je nakazów oznaczonych paragrafami od 1 do 34 (1917: 55). Prócz pewnych śladów edytorskich (Abraham 1917: 55), również treść dodatkowych kanonów ma, zdaniem badacza, świadczyć o ich odrębności. Zawierają one bowiem w większości powtórzenie wcześniejszych postanowień zawartych $\mathrm{w}$ tym samym statucie ${ }^{8}$. Historyk sugeruje, że w świetle przytoczonych dowodów należy przyjąć, iż 9 dalszych kanonów jest zbiorem zawartym w innym, późniejszym zbiorze praw. Dodaje również, że wspomnianych przez niego zabiegów redakcyjnych nie można uznać za błędy, ponieważ trudno posądzać kancelarię arcybiskupa Świnki o niestaranność (więcej zob. Abraham 1917: 56) ${ }^{9}$ (Treść legatu Mikołaja dla jego bratanka Jakusza znajduje się m.in. w Acta capitulorum nec non iudiciorum ecclesiastoricum selecta. Vol. 1, Acta capitulorum Gneznensis, Poznanensis et Vladislaviensis (1408-1530) (Ulanowski (red.) 1984: 352). Fragment mówiący o de stillo seculari... zawarto na stronie 352. Jednakże wątpliwości natury wydawniczej wzbudza również edycja Helcla, który w swoim dziele wydał także statuty synodów poprzedzających ten z 1285 roku. Źródła historyczne (zob. m.in. Ratajczak 2009: 22-23) 10 $^{10}$ ówią o synodzie odbytym w 1257 roku pod przewodnictwem arcybiskupa Pełki. W wydaniach źródłowych (Starodawne... oraz $K D W$ ) autorzy przytoczyli treść także tych postanowień.

Pierwszy z zapisów nosi tytuł Crescente quitodie malitia, a synod nakłada nim karę interdyktu na wszystkich poddanych księcia śląskiego Henryka IV, który

${ }^{7}$ Cyfrowe wydanie Starodawnych... dostępne jest pod poniższym adresem: http://dir.icm.edu. pl/Starodawne_Prawa_Polskiego_Pomniki/Tom_1/.

${ }^{8}$ Szczegółowego porównania kanonów zawartych w części zasadniczej statutu i tych z części dodatkowej dokonał W. Abraham (1917: 55-56).

${ }^{9}$ Dokumentem zawierającym wskazówki redakcyjne dla pisarzy kancelaryjnych było Formulare epistolarum Tomasza z Kapui. W. Karasiewicz stwierdza, że Formulare epistolarum było podarunkiem biskupa poznańskiego Jana II Gerbisza (na podst. dopisku - Trzciński 1909: 128-129, 208). Więcej zob. - przypis 37 na stronie 242 opracowania Karasiewicza (Karasiewicz 1948: 242). Z kolei M. Czyżak w swoim artykule Legat książkowy archidiakona Mikołaja Kickiego dla katedry gnieźnieńskiej. Przyczynek do kultury intelektualnej duchowieństwa wielkopolskiego w pierwszej połowie XV wieku (2010: 17) wskazuje, że formularz de stillo seculari de pulcris et ornatis formis, w którym miało znajdować się m.in. Formulare epistolarum, zawierał również Summa artis dictaminis oraz kolejny zbiór formuł artis notariae. Ta sama autorka podaje za Inventarium Ecclesiae Metropolitanae Gnesnensis z 1608 roku, że w zbiorach biblioteki kapituły gnieźnieńskiej znajdowały się dwa formularze Tomasza z Kapui; przetrwał jeden, który był prawdopodobnie darem arcybiskupa Jakuba Świnki. Podobnie zakłada M. Maciejowski (2007: 58, przyp. 187).

${ }^{10}$ Datę potwierdza również Kodeks Dyplomatyczny Wielkopolski, dostępny w wersji elektronicznej pod adresem: http://www.wbc.poznan.pl/Content/20061/kw_01.html [dostęp: 12.03.2017]. 
dopuścił się uwięzienia biskupa wrocławskiego Tomasza ${ }^{11}$ (szerzej o tym przepisie zob. Subera 1981: 45).

Drugi z kanonów traktował o sprawach administracyjno-kościelnych, a mianowicie o obowiązku nałożonym na prepozyta lub dziekana kapituły, którzy musieli w ciągu ośmiu dni od śmierci biskupa zawiadomić pozostałych biskupów prowincjonalnych o jego zgonie, by pogrzeb mógł odbyć się w sposób uroczysty.

Kanony trzeci i czwarty odnosiły się do zarządzania majątkiem zmarłego biskupa - pozostawione dobra miały znajdować się pod pieczą kapituły katedralnej aż do wyboru i konsekracji nowego biskupa, a każdy, kto chciałby dokonać zaboru rzeczy należących do nieboszczyka, podlegał ekskomunice, bez względu na swój status społeczny.

Wszystkie ze znanych opracowań statutów synodów powszechnych wspominają o czterech kanonach zatwierdzonych przez arcybiskupa Pełkę. Badacze powołują się w tej materii przede wszystkim na analizy Abrahama (zob. Nieznane synody ... 1934: 115-128; Abraham 1917: 50) - czyni tak m.in. Ignacy Subera (1981: 45). Badacz jako podstawę źródłową wskazuje tekst ogłoszony przez Hubego (1856: 8-10). Jednakże ten ostatni w dalszej kolejności przytacza postanowienia innego, nieznanego (w momencie wydania jego pracy), synodu Pełki, które w liczbie pięciu zebrano w rzeczonym statucie (Abraham 1934: 10-13). Podobnie wspomniane wydawnictwo Helcla podaje pięć kanonów zatwierdzonych przez abpa Pełkę na synodzie w 1257 roku.

Z dowodu przeprowadzanego przez Abrahama w Studiach krytycznych do dziejów średniowiecznych synodów prowincjonalnych Kościoła polskiego (1917: 46-53) wynika, że ostatni kanon statutów abpa Pełki jest w istocie przepisem należącym do zbioru praw wydanego przez Jakuba Świnkę po pierwszym zwołanym przez niego synodzie. Nowsze wydania krytyczne statutów synodów prowincjonalnych potwierdzają tezę tego badacza (zob. m.in. Sawicki 1963: $328 n)^{12}$.

Spośród 34 kanonów synodu łęczyckiego z 1285 roku, tylko cztery bezpośrednio regulowały kwestie związane $\mathrm{z}$ nauczaniem i korzystaniem $\mathrm{z}$ języka polskiego. Tekst kanonów podają zarówno Hube, jak i Helcel. Łaciński tekst kanonów 3, 4 i 6 cytuję za edycją Hubego, zaś kanon 5 za wydaniem Helcla, ponieważ interpunkcja przyjęta przez Hubego powoduje, że treść kanonu jest niezrozumiała.

11 Podczas trwania klątwy pozwalano jedynie chrzcić dzieci i udzielać sakramentu pojednania umierającym. Starannie zaznaczono, że zakazuje się dokonywania pochówku chrześcijańskiego na terenie objętym interdyktem. Jednocześnie wskazano, że jeśli diecezja zajmuje teren większy od księstwa, to przepis obowiązuje jedynie na ziemiach podlegających władzy księcia; na proboszczów i kanoników nałożono nakaz ogłaszania ludowi w każdą niedzielę i dni świąteczne ekskomuniki na księcia i jego dwór. W diecezji uwięzionego biskupa dzwony miały pozostać nieużywane, a na nabożeństwa lud miał być wzywany kołatkami, jak to czyni się w Niedzielę Męki Pańskiej. Więcej o konflikcie między możnowładcami zob. Karasiewicz 1948.

12 Zob. również Schlesisches Urkundenbuch, t. III, nr 246 Kolonia 1984 oraz t. V, nr 170 tego wydawnictwa z roku 1993, w którym zawarto m.in. statut z 1285 r. 
Pierwszym z trzech kanonów, który wprost mówił o nauczaniu in polonico, jest kanon 3. Nakazuje się w nim tłumaczyć ludowi po polsku Modlitwę Pańską, Credo oraz Pozdrowienie Anielskie. Krótką wzmiankę nt. tego postanowienia umieścili w swojej książce Tadeusz Silnicki i Kazimierz Gołąb (Silnicki i Gołąb 1956). Fragment tekstu źródłowego przytoczył w swoim podręczniku Zenon Klemensiewicz (1980: 68), jednak nie podał jego thumaczenia. Streszczenie postanowień w języku polskim zamieścił natomiast Ignacy Subera w cytowanym dziele (1981: 50), podobnie Izabela Skierska (2003: 184) (w obu wypadkach jest to jedynie krótka informacja). O rzeczonym statucie nie wspomniał jedynie Stanisław Rospond w książce Kościót w dziejach języka polskiego (1985). Zaś Dorota Rojszczak-Robińska w swoim artykule wymienia wszystkie przytoczone modlitwy, a także Dekalog, na temat którego statuty łęczyckie milczą (2010: 80) ${ }^{13}$.

Caput 3. Statuimus etiam: ut omnes presbyteri, singulis diebus Dominicis, intra missarum sollemnia, dictum symbolum et orationem Dominicam, et salutationem Virginis gloriosae, decantato symbolo, loco sermonis exponere debeant populo in polonico, et festa indicere. Si qui autem, adeo periti fuerint, exponant Evangelium ad bona opera facienda, et vitia fugienda, et ad divinum officium, aut saltem ad Corpus Christi videndum populum inducentes, et ante elevationem campana pulsetur, ut homines concurrant, ac deinde ut orent pro domino Papa et omni gradu Ecclesiae, pro Regibus et principibus, cunctoque populo christiano, pro pace et bono statu terrae, et cunctis, quae sunt universorum et singulorum usibus profutura; specialiter autem pro benefactoribus et patronis, ac generaliter pro vivis et defunctis ibi sepultis (Hube 1856: 167-168).

Kanon 3. Postanawiamy zatem, aby wszyscy prezbiterzy w poszczególne dni pańskie, podczas uroczystych mszy, wyrecytowawszy Credo, w miejsce kazania zobowiązani byli objaśniać ludowi w języku polskim słowo Składu Apostolskiego i Modlitwy Pańskiej, i Pozdrowienie Chwalebnej Dziewicy oraz ogłaszać dni świąteczne. Jeśli zaś którzyś będą ponadto biegli, niech przedstawiają Ewangelię dla dzieł dobrych czynienia i win odpędzania i dla służby bożej, i by na Boże Ciało widzieć ludzi przychodzących [albo „ad videndum Corpus Domini” - traktując ten zwrot jako modlitwę za I. Suberą (1981) - wtrącenie W.S.].

I przed podniesieniem [nakazujemy - wtrącenie W.S.] uderzać w dzwon, aby ludzie wspólnie, także potem, modlili się za papieża i wszystkie stany Kościoła, za królów i książęta, i cały lud chrześcijański, za pokój i dobro kraju, i wszystkich razem, którzy są pomocni wszystkim i każdemu z osobna, szczególnie zaś za dobroczyńców i patronów, także oddzielnie za żywych i zmarłych w tych grobach.

Wykaz modlitw niemal całkowicie powtórzony został za kanonem 26. statutu wrocławskiego (zob. więcej Rospond 1985: 31). Dodanie do niego Pozdrowienia Anielskiego wskazuje na pogłębiający się kult maryjny, ale przede wszystkim

${ }^{13}$ Badaczka prawdopodobnie zasugerowała się fragmentem z cytowanej książki Z. Klemensiewicza, który nieco poniżej wzmianki o postanowieniach synodu łęczyckiego wymienił katalog modlitw codziennych, umieszczając tam również Dekalog. 
urozmaicanie zbioru modlitw codziennych. $\mathrm{Z}$ całą pewnością przełożyło się to na wzrost umiejętności językowych użytkowników polszczyzny, a zwłaszcza kapłanów, którzy zmuszeni zostali do podjęcia wysiłku przetłumaczenia modlitwy na język polski. Przypuszczalnie synod wskazywał, że dotychczasowa działalność kaznodziejska przyniosła zamierzone efekty, skoro nazwał wyjaśniających Ewangelię biegłymi. Wydaje się jednak, że uznano za odpowiednie, aby katechizację ludu prowadzić przez nauczanie podstawowych modlitw i fundamentów wiary w języku polskim. Była to zapewne odpowiedź skierowana przeciwko napływowej ludności niemieckiej, która na wielu terenach zaczęła przeważać nad tubylczą społecznością słowiańskojęzyczną (przypomnijmy: synod wrocławski nakazywał odmawianie podstawowych modlitw in lingua vulgari, co mogło oznaczać zarówno dialekty polszczyzny, jak i czeskiego czy niemieckiego). Jak podają Wojciech Ryszard Rzepka i Wiesław Wydra w Chrestomatii staropolskiej, najstarsze zachowane przekłady modlitw codziennych i Credo pochodzą z końca XIV wieku (1984: 26).

Kolejnym kanonem traktującym o odmawianiu modlitwy w języku polskim jest kanon 4. Zawiera on nakaz odmawiania spowiedzi powszechnej, której incipit przytoczono na końcu. Informacji o tym kanonie nie podali Silnicki i Gołąb, a także Rospond. W swych pracach pisali o nim Klemensiewicz (1980: 68), Subera (1981: 50), Ratajczak (2009: 22) i Rojszczak-Robińska (2010: 80). W języku łacińskim wspomniany tekst prezentuje się następująco:

Caput 4. Praeterea, ut populus suas non subterfugiat ecclesias, maxime in sepulturis eligendis, sed ad eas potius ipsius devotio excitetur, statuimus et firmiter praecipimus observari: ut beneficia et nomina benefactorum ecclesiae cuiuslibet habeantur in scriptis, et post exhortationem huiusmodi publice recitentur, ut pro ipsis fiat oratio specialis; et dies obitus eorum in libris et prope sepulcra parietibus annotetur; et ut eorum anniversarium praesentibus nuncietur, qui ad eorum invitentur exequias. In fine autem exhortationis huiusmodi populus generalem confessionem faciat in haec verba: Kaje się Bogu etc (Hube 1856: 168).

Kanon 4. Dalej, aby lud nie unikał swych kościołów, zwłaszcza na wybranych cmentarzach, lecz dla wywołania jego jeszcze większej pobożności, postanawiamy i stanowczo nakazujemy przestrzegać, by beneficja i imiona któregokolwiek z dobrodziejów kościoła były przechowane na piśmie, i po tym napomnieniu niech zostanie publicznie ogłoszone, aby za tych [zmarłych - wtrącenie W.S.] modlitwa stawała się szczególna; i dni ich śmierci były w księgach i na murach blisko czasu pogrzebu zapisywane; i aby w rocznice śmierci żyjący byli zapraszani na nabożeństwo żałobne. W końcu zaś zachęcony tym sposobem lud spowiedź powszechną niech czyni w te słowa: Kaję się Bogu etc.

Przytoczony fragment statutów łęczyckich wydaje się szczególnie doniosły dla badacza historii języka polskiego. Oto w ostatnich słowach kanonu czwartego odnajdujemy jedno z najstarszych zapisanych polskich zdań: „Kaję się Bogu”. 
Zwrot „etc.” nie należy z całą pewnością do treści modlitwy - jest on elementem kanonu, wskazującym na treściowe rozwinięcie modlitwy po jej incipicie ${ }^{14}$. Dla porównania - omawiany fragment w edycji Helcla: ,[...] populus generalem confessionem faciat in hec verba: «Kayesse Bogu» etc" [wyróżnienie W.S.] (1856: 383-384). Helcel odtwarza nawet grafię podobną do stosowanej w średniowiecznym piśmiennictwie polskim. Wydra i Rzepka w Chrestomatii staropolskiej wskazują, że najstarsze zachowane przekazy spowiedzi powszechnej pochodzą z XV wieku, a do naszych czasów przetrwało kilkanaście wersji tej modlitwy z okresu do połowy XVI wieku (1984: 26).

Kolejnym z kanonów, tym razem dotyczącym nauczania w języku polskim, jest kanon piąty. Przypomnijmy, że w edycjach Hubego i Helcla został umieszczony poza statutem synodu łęczyckiego (jako zapis z nieznanego synodu u Hubego, a u Helcla jako kanon synodu arcybiskupa Pełki z 1257 roku). Jednakże dowód przeprowadzony przez Abrahama w jego artykule pozwolił uznać, że jest to jeden z przepisów ustanowionych w 1285 roku. Treść tego kanonu w wersji łacińskiej przytoczono poniżej:

(§. 5.) Item statuimus, ut omnes ecclesiarum rectores seu plebani, vel quicunque alij sint prelati per uniuersam dyocesin polonice gentis constituti, pro honore suarum ecclesiarum et laudem diuinam, cum habeant scolas per licenciam episcoporum statutas, non ponant Theutonicam gentem ad regendum ipsas, nisi sint polonica lingua ad auctores exponendos pueris et latinum, polonice informati (Helcel 1856: 358).

Krzysztof Ratajczak, przytaczając treść kanonu, stosuje odmienną ortografię i interpunkcję:

Item statuimus, ut omnes ecclesiarum rectores seu plebani, vel qui cunque alii sint prelati per universam dyocesin Polonice gentis constituti, pro honore suarum ecclesiarum et laudem divinam, cum habeant scolas, per licenciam episcoporum statutas, non ponant Theutonicam gentem ad regendum ipsas, nisi sint Polonica lingua, ad auctores exponendos pueros et Latinum Polonice, informati (2009: 22).

Przyjęty przez Ratajczaka sposób zapisu (za Jasińskim 1877: 322) pod względem interpunkcyjnym wydaje się nieprawidłowy. Badacz w przedostatnim wersie tekstu rozdzielił przecinkiem wyrazy Polonice oraz informati. $\mathrm{Z}$ tego powodu w thumaczeniu na język polski znominalizowany czasownik straci swoją przydawkę, przez co całe zdanie może okazać się niezwykle skomplikowane pod względem składniowym (to może prowadzić do niezrozumienia sensu tekstu). Ponieważ interpunkcja zastosowana w tym kanonie jest zbieżna z tą wprowadzoną w edycji Hubego, przekładu dokonałem na podstawie wydania Helcla. Proponuję następujące tłumaczenie tekstu kanonu na język polski:

\footnotetext{
${ }^{14}$ Podobny sposób zapisu pierwszych słów modlitw (np. Oycze nasz etc.) występuje np. w Rozmyślaniach dominikańskich. Zob. Górski, Kuraszkiewicz 1965: 7.
} 
(§. 5.) Również ustanawiamy, by wszyscy rektorzy kościołów albo plebani, albo jacykolwiek inni, którzy są zwierzchnikami za pośrednictwem prawnie ustanowionej wspólnoty diecezji ludu polskiego, dla godności swoich kościołów i [ku - wtrącenie W.S.] chwale bożej, skoro dzięki pozwoleniu Kościoła mają założone szkoły dla kształtowania polszczyzny, niech nie przenoszą pod rządy ludu teutońskiego tychże [szkół - wtrącenie W.S.], jeśli nie potrafią w języku polskim wyjaśniać chłopcom łacińskich autorów i ich dzieł.

Ostatnim z kanonów, który bezpośrednio przedstawia stosunek polskiego Kościoła do mowy jego ludu jest statut 6. Spośród trzech omawianych w niniejszej pracy kanonów, to właśnie jemu badacze poświęcają najwięcej uwagi. Pochylili się nad nim zarówno historycy: Silnicki i Gołąb (1956: 150), Subera (1981: 52); historycy języka: Klemensiewicz (1980: 68), Rospond (1985: 31), Rojszczak-Robińska (2010: 80), Bolz i Żurowska-Górecka (1965: 204); a nawet historycy wychowania, jak np. Ratajczak (2009: 23).

Caput 6. Statuimus insuper, quod ad conservationem et promotionem linguae polonicae, in singulis locis ecclesiarum cathedralium, et conventualium, et aliis quibuscumque locis non ponantur recotres scholarum, nisi linguam polonicam proprie [wyróżnienie W.S.] sciant, et possint pueris auctores repetere sive exponere in polonica lingua (Hube 1856: 168-169).

Kanon 6. Postanawiamy ponadto, że dla zachowania i rozpowszechniania języka polskiego, na poszczególnych stanowiskach kościelnych katedralnych i klasztornych, i innych jakichkolwiek miejscach nie będą osadzani rektorzy szkolni, jeśli nie znają właściwie/dobrze po polsku autorów [łacińskich - wtrącenie W.S.] i nie są w stanie chłopcom powtarzać [ich dzieł - wtrącenie W.S.] albo wykładać w języku polskim ${ }^{15}$.

Powyższy kanon jest szeroko komentowany przez naukowców. Większość z nich wskazuje na szczególną dbałość arcybiskupa Świnki o stan języka polskiego w szkolnictwie i Kościele (zob. Silnicki, Gołąb 1956: 150; Bolz, Żurowska-Górecka za: Leńczuk 2012: 58; Rospond 1985: 31; Rojszczak-Robińska 2010: 80) oraz chęć utrzymania polskości na kolonizowanym Śląsku i w Wielkopolsce (zob. Subera 1981: 52). Mariusz Leńczuk pisze z kolei, że tłumaczenie tekstu z łaciny na polski miało służyć przede wszystkim klerowi parafialnemu, którego poziom wykształcenia musiał być niski, skoro sami biskupi podczas synodu zwrócili uwagę na brak zrozumienia liturgii. Krakowski badacz powołuje się tutaj na kanon siódmy, którym na archidiakonów wizytujących parafie nałożono obowiązek sprawdzania, czy kapłani dostatecznie rozumieją tekst Mszy świętej, znają ceremonie i (co ważne) zapoznali się ze statutami synodu z 1285 roku (Leńczuk 2012: 64).

${ }^{15}$ Za wszystkie uwagi dotyczące przekładu z łaciny dziękuję pani magister Marcie Siwińskiej. 
Rospond w swoim tłumaczeniu kanonu szóstego podał, że nauczycielami w szkołach mają być tylko tacy uczeni, którzy "doskonale znają język polski” (Rospond 1985: 31). Użyte przez badacza pojęcie jest bardzo nieostre, w zasadzie nie pozwala określić, jakim stopniem opanowania polszczyzny powinni wyróżniać się magistrowie szkół katedralnych i klasztornych. Na potrzeby niniejszej pracy przyjęto takie thumaczenie wyrazu proprie, które według Elektronicznego Słownika Łaciny Średniowiecznej w Polsce oznacza 'właściwie, dobrze' (www 1). Zamieszczone przy haśle przykłady wskazują, że w tym konkretnym (kon)tekście chodzi o język polski. Zaproponowany odpowiednik leksykalny, choć także o nieostrym znaczeniu, prawdopodobnie lepiej oddaje sens kanonu (zob. ostatnie zdanie poprzedniego akapitu i nakaz dostatecznego rozumienia tekstu liturgii) ${ }^{16}$.

Postanowienia synodu łęczyckiego z 1285 roku powtórzyli: następca Jakuba na tronie metropolity gnieźnieńskiego Janisław, który w 1326 roku na synodzie w Uniejowie, wydając własne statuty, powtórzył wszystkie nakazy zawarte w zbiorach praw swego poprzednika, oraz biskup wrocławski Nankier, który przy ustanawianiu praw dla własnej diecezji posiłkował się pozostawionymi w spadku po Śwince prawami (Rojszczak-Robińska 2010: 80-81). Dopiero od 1357 roku zaprzestano kompleksowej recepcji kanonów wcześniej wydanych, a działo się to za urzędowania abpa Jarosława. Później zwyczaj przywoływania poprzednich przepisów powtórzył jeszcze abp Mikołaj Trąba, wydając własny zbiór praw w 1420 roku (Silnicki, Gołąb 1956: 158).

Jak wynika z opracowań historycznych i historycznojęzykowych (zob. np. Karasiewicz 1948, Subera 1981, Rospond 1985, Rojszczak-Robińska 2010), działalność XIII-wiecznych synodów powszechnych na ziemiach polskich była nakierowana na wprowadzenie dyscypliny moralnej i administracyjnej kleru względem przełożonych, a także powstrzymanie ekspansji niemieckiego duchowieństwa w polskich diecezjach. Ekspansja ta na pewno nie nosiła cech działalności misyjnej, gdyż metropolia w Gnieźnie była niezależna od tej w Magdeburgu i podlegała bezpośrednio papieżowi. Badacze uznają, że duchowieństwo i mnisi niemieccy starali się wykorzystać rozbicie terytorialne dla interesów własnego Kościoła, który powiększając swoje dobra, zyskiwał większe wpływy z tytułu danin. Dużym ułatwieniem dla tego procederu była prowadzona na zachodnich i południowych ziemiach podzielonego państwa polskiego akcja kolonizacyjna, w ramach której osiedliło się w nowo utworzonych miastach wielu średniozamożnych mieszczan oraz rzemieślników zza Odry.

Wydaje się jednak, że takie przedstawienie sprawy spowodowane jest stereotypami na temat stosunków polsko-niemieckich. Należy zwrócić uwagę, że działalność zakonów na ziemiach zasiedlanych przez kolonistów miała charakter nie tylko ewangelizacyjny, ale też kulturotwórczy. Jak wskazują opracowania historyków Kościoła, przedstawiciele ruchu monastycznego byli doskonale wykształceni,

${ }^{16} \mathrm{O}$ konsekwencjach nieścisłości w interpretacjach kanonu 26. synodu wrocławskiego z 1248 roku dokonanych przez Rosponda zob. Stelmach 2014. 
często kończyli uniwersytety świeckie, dzięki czemu posiadali większe umiejętności krasomówcze niż kapłani po szkołach katedralnych (zob. np. Knowles, Obolensky 1988). Nic więc dziwnego, że swoimi kazaniami przyciągali do kościołów tłumy wiernych, którzy - siłą rzeczy - rezygnowali z udziału w liturgii w kościele parafialnym. Skład osobowy zakonów w początkach istnienia Kościoła w Polsce często opierał się na przybyszach z Zachodu - Włochach, Niemcach, czy choćby wcześniej schrystianizowanych Czechach. Dlatego ich wpływy zaznaczały się bardzo wyraźnie zwłaszcza na ziemiach, które podczas rozbicia dzielnicowego stawały się terenami chętnie zasiedlanymi przez ludność napływową. Episkopat, wprowadzając na synodzie w Łęczycy nakaz przyjmowania na stanowisko nauczycieli tylko osób polskojęzycznych, pokazał, że pragnie wzmocnić rangę polszczyzny wobec języka niemieckiego i łaciny. Chciał też zapewne położyć większy nacisk na wykształcenie kleru parafialnego, który bardzo często nie rozumiał liturgii. A to nie mogło cieszyć biskupów, którzy obserwowali odpływ wiernych do kościołów pozostających pod opieką (często niemieckich) mnichów.

Podstawą działalności synodalnej były konstytucje soborowe z 1215 roku oraz kanon 26. statutu synodu wrocławskiego $\mathrm{z}$ roku 1248. Znając te dokumenty, a zwłaszcza drugi z wymienionych, miał synod łęczycki oparcie kanoniczne dla swoich poczynań zmierzających do propagowania polszczyzny. Spojrzenie na jego ustawodawstwo w tym szerokim kontekście umożliwia odpowiednie zrozumienie nowatorstwa statutu łęczyckiego, zwłaszcza w skali kraju. Bowiem, o ile synod we Wrocławiu promował odmawianie modlitw w języku ludu (co nie oznaczało wprost polszczyzny), to już kanon trzeci synodu w Łęczycy wyraźnie nakazuje recytowanie modlitw z ludem po polsku. Jest to dalece posunięte uszczegółowienie przepisów prawa kościelnego, które stanowiło znak czasu - polski episkopat musiał dać odpór kolonizacyjnym zapędom Niemców i zachować wiernych we własnej jurysdykcji ${ }^{17}$.

${ }^{17}$ Tym artykułem chciałem również zwrócić uwagę środowiska naukowego na potrzebę dokonywania filologicznych przekładów źródeł łacińskich. Ograniczenie kontaktu studentów kierunków humanistycznych (w tym filologicznych) z łaciną powoduje, że teksty źródłowe, w tym tak istotne dla badaczy historii języka jak dokumenty synodalne, są dla wielu z nich niezrozumiałe. Co prawda w monografiach lub artykułach dotyczących konkretnego problemu znaleźć można robocze przekłady lub streszczenia poszczególnych kanonów, jednakże często są one niedokładne, przez co mogą prowadzić do błędnych wniosków (por. np. Rospond 1985; Rojszczak-Robińska 2010). Pragnę podkreślić, że mam świadomość, iż każdy przekład jest interpretacją, co jednak nie zmienia faktu, że rzetelny przekład tekstu źródłowego może ułatwić kolejnym pokoleniom badaczy, nieznającym łaciny lub znającym ją niedostatecznie, aktualizację stanu badań nad historią zewnętrzną języka. 


\section{Bibliografia}

\section{Literatura podmiotowa}

Helcel A., 1856, Starodawne prawa polskiego pomniki, t. 1, Warszawa.

Hube R., 1856, Antiquissimae constitutiones synodales provinciae gneznensis. Maxima ex parte. Nunc primum e codicibus manu scriptis typis mandatae, Petropoli.

\section{Literatura przedmiotowa}

www 1 - Elektroniczny słownik łaciny średniowiecznej w Polsce, http://scriptores.pl/ elexicon/pl/lemma/proprie\#II_1_sense_a [dostęp: 3.01.2019].

Abraham W., 1917, Studia krytyczne do dziejów średniowiecznych synodów prowincjonalnych Kościoła polskiego, Kraków.

Abraham W., 1934, Nieznane synody i nieznane statuty, „Collectanea Theologica”, nr 15, s. $115-128$.

Bolz B., Żurowska-Górecka W., 1965, Glosy kanonu z lat 1428-1431 (z rękopisu gnieźnieńskiego $n r$ 60), „Slavia Occidentalis”, nr 25, s. 203-231.

Chrestomatia staropolska. Teksty do roku 1543, 1984, red. W.R. Rzepka, W. Wydra, Wrocław.

Czyżak M., 2010, Legat książowy archidiakona Mikołaja Kickiego dla katedry gnieźnieńskiej. Przyczynek do kultury intelektualnej duchowieństwa wielkopolskiego w pierwszej połowie XV wieku, w: Ecclesia. Studia z Dziejów Wielkopolski, red. F. Lenort, P.F. Neumann, t. 5, Poznań, s. 7-27.

ESŁŚwP - Elektroniczny Słownik Łaciny Średniowiecznej w Polsce, http://scriptores.pl/ elexicon/pl/lemma/proprie\#II_1_sense_a [dostęp: 22.10.2018].

Górski K., Kuraszkiewicz W. (red.), 1965, Rozmyślania dominikańskie, Wrocław.

Irgang W. (red.), Schlesisches Urkundenbuch, 1963-1998, red. H. Appelt, t. I, red. t. II-VI, Kolonia.

Jasiński T., 1877, Kodeks dyplomatyczny Wielkopolski, t. 1, Poznań.

Karasiewicz W., 1948, Jakób II Świnka arcybiskup gnieźnieński 1283-1314, Poznań.

Klemensiewicz Z., 1980, Historia języka polskiego, Warszawa.

Knowles D., Obolensky D., 1988, Historia Kościoła. 2, 600-1500, przeł. R. Turzyński, t. 2, Warszawa.

Leńczuk M., 2013, Staropolskie przekazy kanonu Mszy Świętej. Wariantywność leksykalna, Warszawa.

Maciejowski M., 2007, Orientacje polityczne biskupów metropolii gnieźnieńskiej 12831320, Kraków.

Nieznane synody i nieznane statuty, „Collectanea Theologica”, 1934, 15/12, s. 115-128; http://bazhum.muzhp.pl/media//files/Collectanea_Theologica/Collectanea_Theologica-r1934-t15-n2/Collectanea_Theologica-r1934-t15-n2-s115-128/Collectanea_Theologica-r1934-t15-n2-s115-128.pdf [dostęp: 12.03.2017].

Ratajczak K., 2009, Ustawodawstwo szkolne wczesnośredniowiecznych soborów powszechnych i wybranych synodów. Zarys problemów, w: Ars educanci. Źródła. Studia $z$ dziejów wychowania i ksztatcenia od średniowiecza do XIX wieku, red. J. Gwioździk, P.P. Barczyk, Mysłowice, s. 13-25. 
Rojszczak-Robińska D., 2010, Język a Kościót, „Kwartalnik Językoznawczy”, nr 2, s. 76-91.

Rospond S., 1985, Kościół w dziejach języka polskiego, Wrocław.

Sawicki J., 1948-1963, Concilia Poloniae: źródła i studia krytyczne, t. I-X, Warszawa.

Silnicki T., Gołąb K., 1956, Arcybiskup Jakub Świnka i jego epoka, Warszawa.

Skierska I., 2003, Obowiązek mszalny w średniowiecznej Polsce, Warszawa.

Stelmach W., 2014, Reinterpretacja filologiczna kanonu 26. synodu wrocławskiego z 1248 roku a jego funkcjonowanie $w$ dydaktyce akademickiej, „Kwartalnik Językoznawczy”, nr 4, s. 20-35.

Subera I., 1981, Synody prowincjonalne arcybiskupów gnieźnieńskich. Wybór tekstów ze zbioru Jana Wężya z r. 1761, Akademia Teologii Katolickiej, Warszawa.

Ulanowski B. (red.), 1984, Monumenta medii aevii historica res gestas poloniae illustrantia, t. XIII, Akademia Umiejętności, Kraków. 